\title{
Uji daya hambat jamur endofit rimpang lengkuas (Alpinia galanga 1.) terhadap pertumbuhan bakteri Escherichia coli dan Staphylococcus aureus
}

\author{
${ }^{1}$ Vita A. D. Putri \\ ${ }^{2}$ Jimmy Posangi \\ ${ }^{2}$ Edward Nangoy \\ ${ }^{2}$ Robert A. Bara
}

\author{
${ }^{1}$ Kandidat Skripsi Fakultas Kedokteran Universitas Sam Ratulangi Manado \\ ${ }^{2}$ Bagian Farmakologi dan Terapi Fakultas Kedokteran Universitas Sam Ratulangi Manado \\ Email: Vitaputri11@yahoo.com
}

\begin{abstract}
Endophytic fungi could be used as an alternative antibiotic because it produced bioactive compounds, which are developed as basic ingredients for medicine such as antibiotic, antioxcide, anticancer. Endophytic fungi can be isolated from Rhizome of Alpinia galanga $\mathrm{L}$. which is abundant in Indonesia. The aim of this study was to find the inhibiting zone of endophytic fungi rhizome of Alpinia galanga L. to the growth of Staphylococcus aueus and Escherichia coli. This was an experimental laboratory study using modified Kirby-Bauer well diffusion technique in Marine Pharmaceutical and Biology Molecular laboratory of FPIK faculty in Sam Ratulangi University. Endophytic fungi were produced by Rhizome of Alpinia galanga L. which are cultured in carbohydrate-rich media. Then, it produced various fungi isolate, which is being used for testing its bioactiy to Staphylococcus aureus and Escherichia coli. The results showed that only 2 isolates of endophytic fungi that have inhibitory and the range of the average value of inhibition zone endophytic fungi rhizome of Alpinia galanga $\mathrm{L}$. against Staphylococcus aureus $19 \mathrm{~mm}$ to $21.3 \mathrm{~mm}$, while the Escherichia coli $21.3 \mathrm{~mm}$ to $22.3 \mathrm{~mm}$. Conclusion: Endophytic fungi Rhizome of Alpinia galanga L. could inhibit the bacterial growth of Staphylococcus aureus and Escherichia coli.
\end{abstract}

Keywords: Staphylococcus aureus, Escherichia coli, endophytic fungi

\begin{abstract}
Abstrak: Jamur endofit salah satu sumber bahan baku obat yang memproduksi senyawa bioaktif potensial dalam menghasilkan efek antibiotik, antikanker, antioksidan. Jamur endofit dapat ditemukan pada tanaman Lengkuas Alpinia galanga L. yang banyak terdapat di Indonesia. Penelitian ini bertujuan untuk mengetahui daya hambat jamur endofit terhadap Staphylococcus aureus dan Escherichia coli. Jenis penelitian ialah eksperimental laboratorik dengan modifikasi Kirby-Bauer sumuran di Laboratorium Biologi Molekular dan Farmasetika Laut FPIK-UNSRAT. Jamur endofit yang dihasilkan dari rimpang Lengkuas Alpinia galanga L. yang dikultur dalam media kaya karbohidrat menghasilkan berbagai isolat jamur yang kemudian diuji bioaktivitasnya terhadap Staphylococcus aureus dan Escherichia coli. Hasil penelitian mendapatkan hanya 2 isolat jamur endofit yang memiliki daya hambat dan kisaran nilai rata-rata zona hambat jamur endofit rimpang Lengkuas Alpinia galanga L. terhadap Staphylococcus aureus $19 \mathrm{~mm}$ sampai dengan 21,3 mm, sedangkan terhadap Escherichia coli $21,3 \mathrm{~mm}$ sampai dengan 22,3 mm. Simpulan: Jamur endofit rimpang lengkuas Alpinia galanga L. dapat menghambat pertumbuhan Staphylococcus aureus dan Escherichia coli. Daya hambat jamur endofit lebih besar pada Escherichia coli daripada Staphylococcus.
\end{abstract}

Kata kunci: Staphylococcus aureus, Escherichia coli, jamur endofit 
Tanaman merupakan salah satu sumber daya yang sangat penting dalam upaya pengobatan. Sampai saat ini seperempat dari obat-obat modern yang beredar di dunia berasal dari bahan aktif yang diisolasi dan dikembangkan dari tanaman. ${ }^{1}$

Jamur endofit merupakan mikroorganisme yang tumbuh dalam jaringan tumbuhan tanpa menimbulkan efek negatif bahkan bersifat simbiosis mutualisme dengan tanaman inangnya, jamur endofit dapat diisolasi dari akar, biji, batang, daun, bunga, dan buah tumbuhan serta dapat menghasilkan senyawa-senyawa bioaktif yang berkhasiat untuk dikembangkan sebagai bahan baku obat. Dari 300.000 spesies tumbuhan tingkat tinggi yang ada di bumi, masing-masing individu tumbuhan merupakan inang dari jamur endofit. ${ }^{2}$ Saat ini, beberapa produk bioaktif dari jamur endofit yang telah diisolasi dan diidentifikasi memiliki aktivitas biologis tinggi sebagai antikanker, antioksidan, dan antibakteri. ${ }^{3}$

Salah satu jenis tumbuhan yang banyak digunakan sebagai obat tradisional ialah lengkuas (Alpinia galanga L.). Beberapa penelitian yang pernah dilakukan sebelumnya, rimpang lengkuas memiliki berbagai khasiat diantaranya sebagai antijamur dan antibakteri. ${ }^{4}$

Resistensi antibiotik merupakan permasalahan penting di bidang kesehatan. Berbagai jenis kuman patogen berkembang menjadi resisten terhadap satu atau beberapa jenis antibiotik. Munculnya bakteri patogen yang resisten terhadap satu atau beberapa jenis antibiotik tertentu sangat menyulitkan proses pengobatan penyakit infeksi. $^{5}$

Melihat kecenderungan masalah tersebut di atas, peneliti tertarik melakukan penelitian untuk melihat uji daya hambat yang dihasilkan dari jamur endofit lengkuas (Alpinia galanga L.).

\section{METODE PENELITIAN}

Penelitian eksperimental laboratorium ini dilakukan di Laboratorium Biologi Molekular dan Farmasetika Laut FPIK Universitas Sam Ratulangi. Penelitian ini dilaksanakan pada bulan November Desember 2016.

Tahap-tahap penelitian ialah sterilisasi alat, pembuatan media Cassava Agar (CA) dan media nasi untuk pertumbuhan jamur, Nutrient Agar (NA) untuk pertumbuhan bakteri, media kombinasi (CA dan NA) untuk pengujian pertama. Isolasi jamur endofit dari rimpang lengkuas Alpinia galanga L. kemudian dimurnikan, suspensi bakteri dan pengujian bakteri. Ekstrak jamur endofit dengan cara maserasi, lalu dilakukan pengujian kedua. Kloramfenikol sebagai kontrol positif sedangkan Aquadest sebagai kontrol negatif. Ekstrak jamur endofit, kontrol positif dan kontrol negatif diteteskan sebanyak $100 \mu \mathrm{l}$ pada sumur yang berbeda, kemudian cawan petri dimasukkan dalam inkubator pada suhu $37^{\circ} \mathrm{C}$ selama 24 jam. Diamati dan diukur diameter zona hambat yang terbentuk dengan menggunakan mistar selama 3 hari pada pengujian pertama di media kombinasi (CA dan NA) dan dalam 3 kali pengulangan pada pengujian kedua di media Nutrient Agar (NA).

Zona hambat adalah daerah jernih di sekeliling sumur dari media pertumbuhan bakteri uji yang tidak ditumbuhi bakteri. Lebar diameter zona hambat diukur dengan mistar dalam satuan sentimeter.

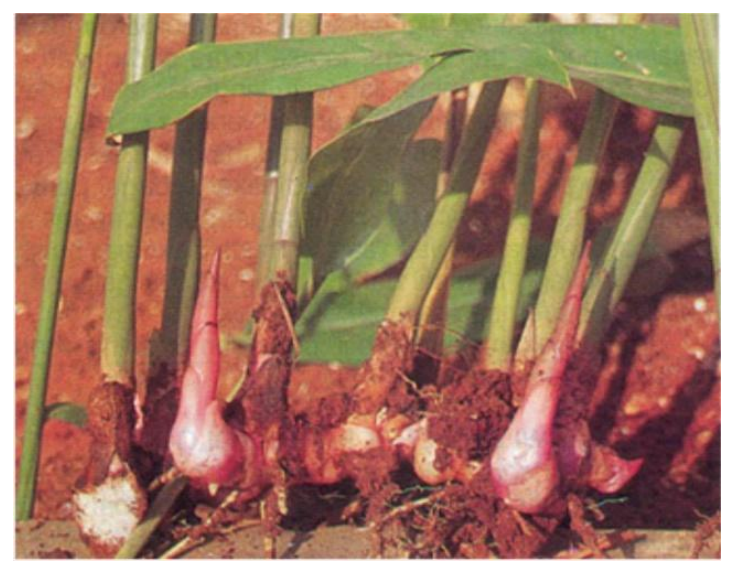

Gambar 1. Tanaman Lengkuas

\section{HASIL PENELITIAN}

Pembiakan jamur endofit yang berasal dari rimpang lengkuas yang diambil dari 2 lokasi berbeda menghasilkan 4 jenis jamur. Rimpang lengkuas dari Kecamatan 
Malalayang, hanya menghasilkan satu jenis jamur endofit sedangkan rimpang lengkuas dari kecamatan kairagi, menghasilkan tiga jenis jamur endofit. kemudian dimurnikan sehingga mendapat 4 jenis jamur endofit yang murni secara makroskopik.

Tabel 1. Morfologi koloni isolat jamur endofit dari rimpang lengkuas Alpinia galanga $\mathrm{L}$.

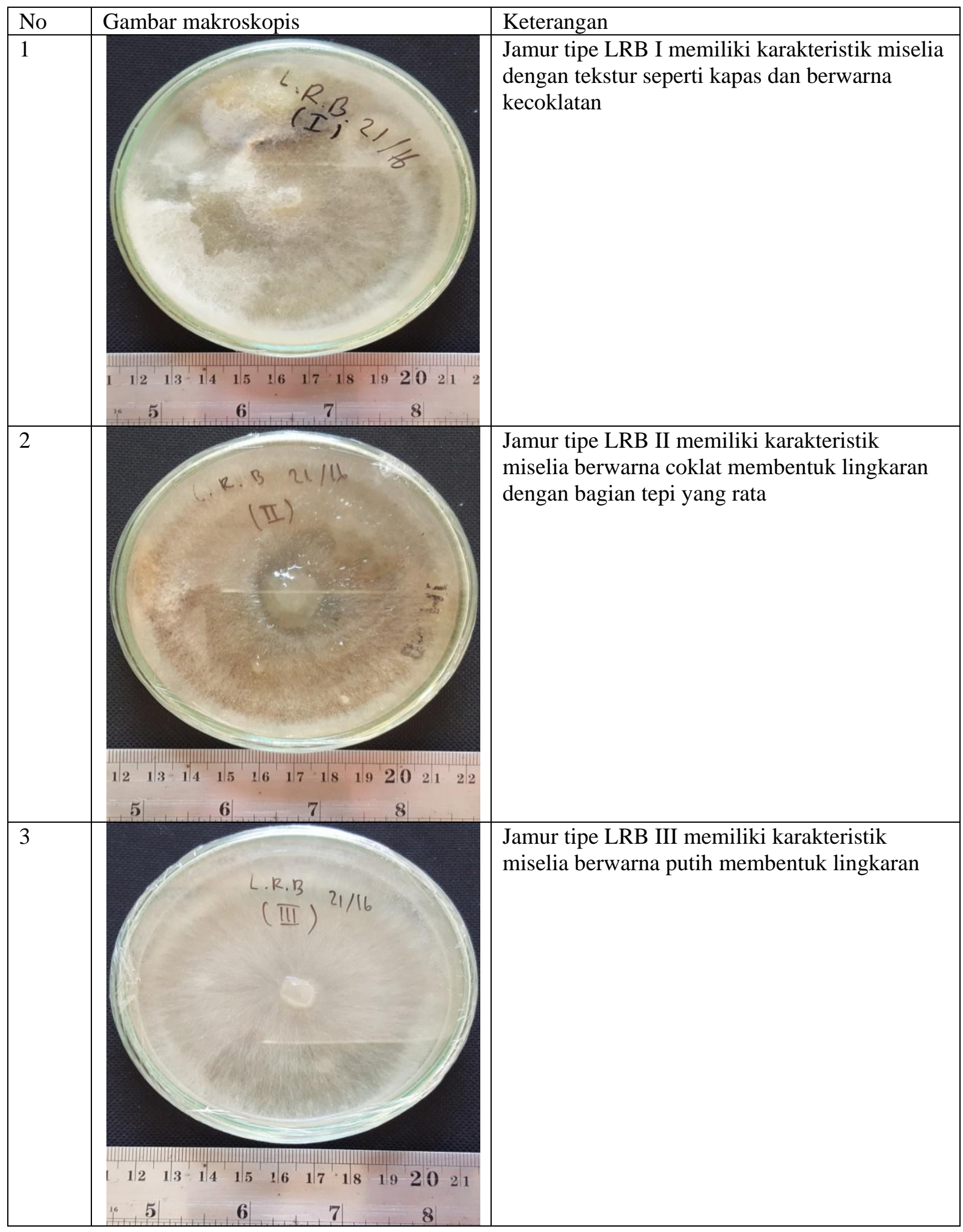


Putri, Posangi, Nangoy, Bara: Uji daya hambat...

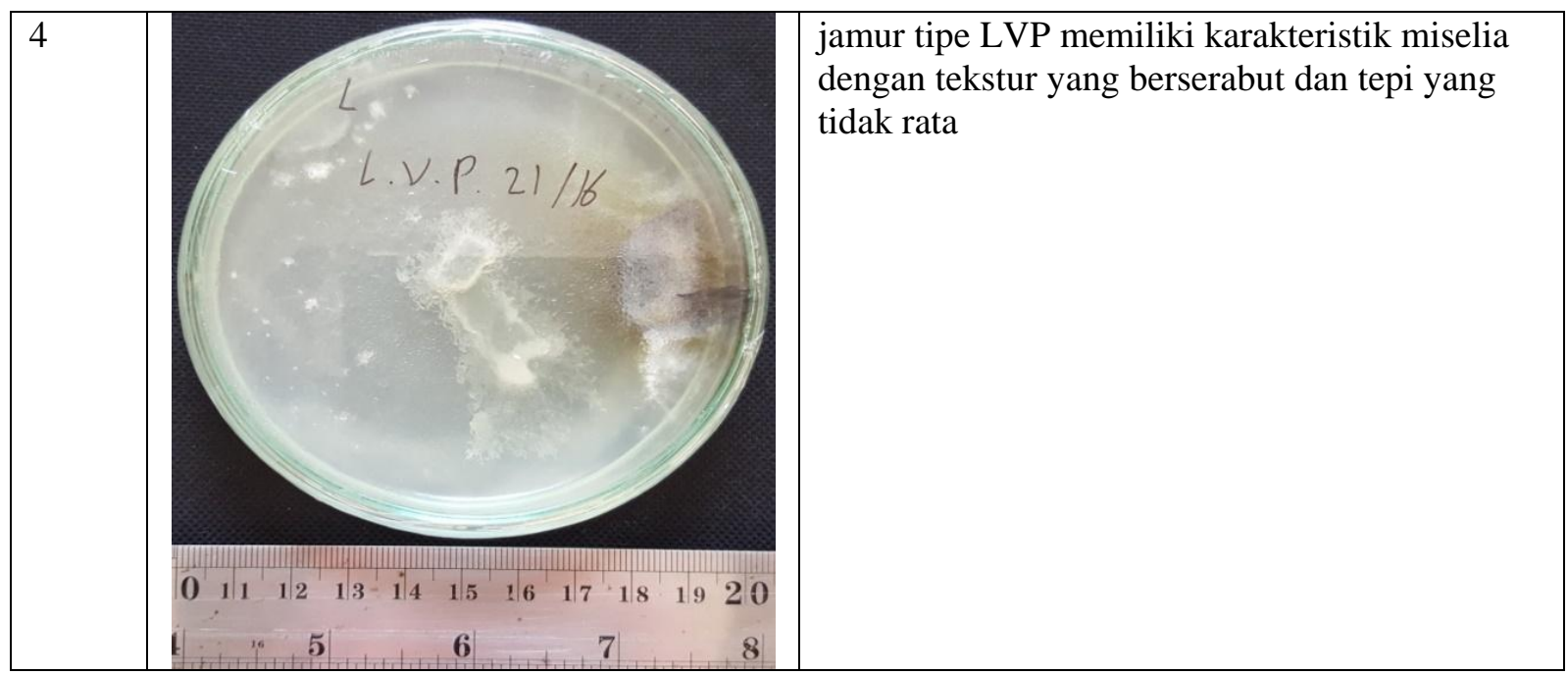

Catatan : LRB (Lengkuas Robert Bara) yang diambil dari daerah Kairagi, Kecamatan Mapanget, Manado. LVP (Lengkuas Vita Putri) yang diambil dari daerah Tanah Putih, Kecamatan Malalayang, Manado

\section{A. Penelitian bakteri Staphylococcus} aureus dan Escherichia coli selama 3 hari

Jamur endofit yang tumbuh dari potongan rimpang lengkuas yang ditanam pada media agar singkong (cassava agar). Bakteri uji Staphylococcus aureus yang telah diolesi pada media kombinasi ditanam 4 isolat jamur endofit tersebut dan kloramfenikol sebagai kontrol positif. Hal yang sama dilakukan juga pada bakteri Escherichia coli.

Tabel 2. hasil uji efek antibakteri jamur endofit dari media cassava agar terhadap petumbuhan bakteri Staphylococcus aureus

\begin{tabular}{cccccc}
\hline Hari & \multicolumn{5}{c}{ Diameter zona hambat $(\mathbf{m m})$} \\
\cline { 2 - 6 } & LRB I & LRB II & LRB III & LVP & Kloramfenikol \\
\hline 1 & 20 & 18 & - & - & 30 \\
2 & 22 & 20 & - & - & 30 \\
3 & 22 & 20 & - & - & 30 \\
\hline
\end{tabular}

Tabel 3. hasil uji efek antibakteri jamur endofit dari media cassava agar terhadap petumbuhan bakteri Escherichia coli

\begin{tabular}{cccccc}
\hline Hari & \multicolumn{5}{c}{ Diameter zona hambat $(\mathbf{m m})$} \\
\cline { 2 - 6 } & LRB I & LRB II & LRB III & LVP & Kloramfenikol \\
\hline 1 & 20 & 23 & - & - & 30 \\
2 & 20 & 23 & - & - & 30 \\
3 & 0 & 0 & - & - & 30 \\
\hline
\end{tabular}

B. Kultivasi jamur endofit yang memiliki efek antibakteri pada media nasi

Dari 4 sampel jamur endofit yang telah diuji didapatkan hanya 2 sampel jamur endofit yang memiliki daya hambat pada kedua bakteri tersebut, yaitu jamur tipe LRB I dan jamur tipe LRB II. Kedua sampel jamur ini kemudian dikultivasi pada media nasi agar diperoleh biomassa yang lebih banyak kemudian diekstrak untuk selanjutnya akan diuji kembali. Jamur tipe LRB I dikultivasi pada dua Erlenmeyer, dan jamur tipe LRB II dikultivasi pada satu Erlenmeyer, sehingga didapatkan 3 isolat jamur endofit yang akan diuji kembali. 
C. Uji aktivitas antibakteri dari ekstrak jamur

Ekstrak dari jamur endofit tersebut kemudian diuji lagi pada bakteri Staphylococcus aureus dan Escherichia coli. Bakteri uji Staphylococcus aureus yang telah diolesi pada media NA (nutrient agar) ditanam 3 jamur endofit tersebut, aquadest sebagai kontrol negatif, dan kloramfenikol sebagai kontrol positif. Hal yang sama dilakukan juga pada bakteri Escherichia coli.

Tabel 4. hasil uji efek antibakteri jamur endofit dari ekstrak jamur terhadap petumbuhan bakteri Staphylococcus aureus

\begin{tabular}{ccccc}
\hline Kode isolate & \multicolumn{3}{c}{ Diameter zona hambat (mm) } & Rata-rata \\
\cline { 2 - 4 } & Pengulangan 1 & Pengulangan 2 & Pengulangan 3 & \\
\hline LRB Ia & 19 & 17 & 21 & \pm 19 \\
LRB Ib & 21 & 20 & 19 & \pm 20 \\
LRB II & 22 & 20 & 22 & $\pm 21,3$ \\
Kloramfenikol (+) & 30 & 30 & 29 & $\pm 29,7$ \\
Aquadest (-) & - & - & - & - \\
\hline
\end{tabular}

Tabel 5. hasil uji efek antibakteri jamur endofit dari ekstrak jamur terhadap petumbuhan bakteri Escherichia coli

\begin{tabular}{ccccc}
\hline Kode isolat & \multicolumn{3}{c}{ Diameter zona hambat (mm) } & Rata-rata \\
\cline { 2 - 4 } & Pengulangan 1 & Pengulangan 2 & Pengulangan 3 & \\
\hline LRB Ia & 20 & 21 & 23 & $\pm 21,3$ \\
LRB Ib & 21 & 23 & 20 & $\pm 21,3$ \\
LRB II & 23 & 22 & 22 & $\pm 22,3$ \\
Kloramfenikol (+) & 30 & 32 & 30 & $\pm 30,7$ \\
Aquadest (-) & - & - & - & - \\
\hline
\end{tabular}

\section{BAHASAN}

Pada penelitian ini didapatkan 4 isolat jamur endofit dari rimpang lengkuas Alpinia galanga $\mathrm{L}$, yang diambil dari dua lokasi yang berbeda. Pada kecamatan Malalayang di dapatkan 1 isolat jamur endofit dan pada kecamatan Mapanget didapatkan 3 isolat jamur endofit. Hal ini berkaitan dengan tempat hidup endofit dengan sifat yang unik, sehingga endofit yang terdapat pada tumbuhan yang berasal dari spesies yang sama akan bervariasi di habitat yang berbeda. Secara makroskopik isolat jamur endofit tersebut menghasilkan jenis isolat yang berbeda-beda atau memiliki karakteristik miselia yang bervariasi, baik pada warna koloni, bentuk koloni, dan tekstur koloninya. Menurut penelitian yang dilakukan oleh Noverita, hal ini merupakan mekanisme adaptasi dari endofit terhadap mikroekologi dan kondisi fisiologis yang spesifik dari masing-masing tumbuhan inang. ${ }^{6}$ Pada satu bagian tumbuhan dapat isolasi lebih dari satu jenis jamur endofit, dan juga pada penelian yang dilakukan oleh Pertini dkk, menjelaskan bahwa kehadiran jenis jamur endofit dihubungkan dengan kondisi mikrohabitat tanaman inang dan kecocokan genotip antara tanaman inang dan jamur endofit, sehingga akan berpengaruh terhadap perbedaan dalam komposisi koloni jamur endofit pada lokasi yang sama. ${ }^{7}$ Jamur endofit tersebut diuji menggunakan 2 jenis bakteri, yaitu Staphylococcus aureus mewakili bakteri Gram positif dan Escherichia coli mewakili bakteri Gram negatif.

Hasil pengujian 4 isolat jamur endofit itu menunjukkan adanya zona hambat (clear zone) pada kedua bakteri uji tersebut. Namun pada keempat isolat jamur endofit 
yang diperoleh, terlihat hanya 2 isolat saja yang memiliki zona hambat sedangkan 2 isolat lainnya tidak memperlihatkan adanya zona hambat. Hal ini mungkin dapat disebabkan karena 2 isolat jamur endofit tersebut menghasilkan senyawa-senyawa aktif antibakteri seperti flavonoid, fenol, alkaloid, tannin, saponin, dll, sedangkan 2 isolat lainnya kemungkinan tidak memproduksi senyawa aktif antibakteri. 2 isolat jamur endofit yang memiliki zona hambat ini dikultivasi pada media nasi untuk mendapatkan biomassa yang lebih banyak, lalu diekstrak dengan cara maserasi yang bertujuan untuk mengeluarkan senyawa dari bagian tubuh organisme. Pelarut yang digunakan adalah etanol 95\%, Kemudian diuapkan menggunakan Rotary vacuum evaporator yang bertujuan untuk memekatkan konsentrasi larutan sehingga didapatkan larutan dengan konsentrasi yang lebih tinggi. ${ }^{8}$

Berdasarkan hasil pengamatan dengan 3 kali pengulangan uji antibakteri dari ekstrak jamur endofit rimpang lengkuas, memperlihatkan adanya zona hambat (clear zone). Hal ini dapat dilihat pada pembentukan zona hambat baik pada koloni bakteri Staphylococcus aureus maupun Escherichia coli. Penelitian yang dilakukan oleh Kusriani dkk menemukan bahwa senyawa-senyawa aktif golongan flavonoid, saponin, dan steroid/triterpenoid terdapat pada ekstrak lengkuas, ${ }^{9}$ yang diduga merupakan senyawa yang berperan dalam menghambat pertumbuhan kedua bakteri tersebut.

Senyawa flavonoid merupakan golongan terbesar dari senyawa fenol dan memiliki mekanisme kerja dalam menghambat pertumbuhan bakteri dengan cara inaktivasi protein pada membran sel sehingga mengakibatkan struktur protein menjadi rusak. ${ }^{10}$

Senyawa saponin dapat melakukan mekanisme penghambatan dengan cara membentuk senyawa kompleks dengan membran sel melalui ikatan hydrogen sehingga mengganggu dan mengurangi kestabilan membran sel, menyebabkan sitoplasma bocor keluar dari sel yang akhirnya dapat menimbulkan kematian sel. $^{11}$

Senyawa steroid merupakan golongan senyawa triterpenoid, bereaksi dengan porin (protein transmembran) pada membran luar dinding sel bakteri, membentuk ikatan polimer yang kuat sehingga mengakibatkan rusaknya porin. Dan membuat pertumbuhan bakteri terhambat atau mati. ${ }^{12}$

Menurut penelitian yang dilakukan Strobel, hubungan yang erat antara jamur endofit dan tanaman inangnya ialah transfer materi genetik satu dengan lainnya sehingga jamur endofit dapat menghasilkan metabolit sekunder atau senyawa bioaktif yang sama dengan inangnya. ${ }^{13}$

Pada hasil pengukuran rerata zona hambat kedua isolat jamur endofit yang dikultivasi pada media nasi, didapatkan rata-rata zona hambat yang berbeda-beda. Kisaran zona hambat pada bakteri Staphylococcus aureus ialah $19 \mathrm{~mm}$ sampai dengan 21,3 mm, dan kisaran zona hambat pada bakteri Escherichia coli ialah 21,3 mm sampai dengan 22,3 mm. Berdasarkan hasil tersebut, terlihat bahwa daya hambat terhadap pertumbuhan bakteri Escherichia coli lebih besar dibandingkan dengan bakteri Staphylococcus aureus. Hal ini dapat dikarenakan komponen penyusun dinding sel dari masing-masing bakteri tersebut berbeda. Pada bakteri Gram positif mempunyai struktur dinding berlapis tebal (20-80 nm) dan mengandung peptidoglikan lebih dari $50-80 \%$ berat total dinding sel, akibatnya dinding sel berukuran sangat besar dan kompleks, sehingga zat antibakteri sulit untuk menembus ke dalam sel. Pada bakteri Gram negatif mempunyai struktur dinding sel yang lebih tipis (5-10 $\mathrm{nm})$ dan mengandung peptidoglikan yang lebih sedikit dibandingkan dengan bakteri Gram positif sehingga zat antibakteri dapat masuk dengan lebih mudah ke dalam sel. ${ }^{14}$ Hal ini dapat menunjukkan bahwa senyawa aktif terhadap Gram negatif lebih dominan dibandingkan dengan senyawa aktif terhadap Gram positif.

Antibiotik yang digunakan dalam 
penelitian ini sebagai kontrol positif adalah kloramfenikol, untuk membandingkan efek antibakteri yang dimiliki jamur endofit rimpang lengkuas. Kloramfenikol memiliki mekanisme aksi menghambat pertumbuhan bakteri dengan mekanisme menghambat sintesis protein dengan jalan mencegah pemanjangan rantai protein dengan menghambat aktivitas enzim peptidil transferase pada ribosom bakteri. Senyawa ini secara spesifik terikat pada subunit ribosom 50S dan mencegah formasi ikatan peptide. Kloramfenikol juga merupakan antibiotik bersifat bakteriostatik yang menghambat sintesis protein sel mikroba dan berspektrum luas yang aktif untuk bakteri Gram positif maupun Gram negatif. ${ }^{15}$ Aquadest sebagai kontrol negatif tidak menunjukkan adanya zona hambat, karena tidak memiliki senyawa-senyawa aktif.

Hasil yang diperoleh dalam penelitian ini menunjukkan bahwa isolat jamur endofit yang diperoleh dari rimpang lengkuas (Alpinia galanga L.) memiliki potensi yang besar untuk diteliti lebih lanjut menjadi bahan baku obat dan tidak tertutup pula kemungkinan bahwa jamurjamur endofit ini juga memproduksi senyawa-senyawa bioaktif lain yang bermanfaat sebagai bahan baku obat, misalnya yang memiliki aktivitas antikanker, antivirus, dan lain sebagainya.

\section{SIMPULAN}

Jamur endofit rimpang Lengkuas Alpinia galanga L. berpotensi memiliki efek antibakteri dalam menghambat pertumbuhan bakteri S.aureus dan E.coli. Daya hambat ekstrak jamur endoft lebih besar pada Escherichia coli daripada Escherichia coli.

\section{DAFTAR PUSTAKA}

1. Ernawati S, Noverita, Dinah F. Daya antibakteri jamur endofit yang diisolasi dari daun dan rimpang lengkuas (Alpinia galanga Sw.). Jurnal Farmasi Indonesia. 2009;4(4); p. $161-70$

2. Noverita. Isolasi dan uji aktivtas antibakteri jamur endofit dari daun dan rimpang Zingiber ottensi Val. Jurnal farmasi Indonesia. 2009;4(4)

3. Purwaningsih NV. Daya bunuh ekstrak daun srikaya (Annona Squamosa L.) terhadap telur dan larva Aedes aegypti. [Tesis]. [Denpasar]: Universitas Udayana;2015.

4. Saxena M, Saxena J,Nema R, Singh D, Gupta A. Phytochemistry of medicinal plants. J Pharmacogn Phytochem.2013;1(6):170.

5. Camilleri A, Murray JA. Infeksi Saluran Cerna. In: Longo DL, Fauci AS. Harrison Gastroenterologi dan Hepatologi.Jakarta:EGC;2014:214..

6. Ernawati S, Noverita, Dinah F. Daya antibakteri jamur endofit yang diisolasi dari daun dan rimpang lengkuas (Alpinia galanga Sw.). Jurnal Farmasi Indonesia. 2009;4(4); p. $161-70$

7. Noverita. Isolasi dan uji aktivtas antibakteri jamur endofit dari daun dan rimpang Zingiber ottensi Val. Jurnal farmasi Indonesia. 2009;4(4)

8. Voight R. Buku pelajaran teknologi farmasi, diterjemahkan oleh Soendari Noerono. Gajah Mada University Press. Yogyakarta. 1995; p. 566-67

9. Kusriani H R, Shofia Z. Skrinning fitokimia dan penetapan kadar senyawa fenolik total ekstrak rimpang lengkuas merah dan rimpang lengkuas putih (Alpinia galanga L.). Prosiding Seminar Nasional Penelitian dan PKM Kesehatan. 2015;1(1); p. 295-302

10. Rinawati. Daya antibakteri tumbuhan majapahit (Crescentia cujete L.) terhadap bakteri Vibrio alginolyticus. Institut Teknologi Sepuluh November. Surabaya 2010

11. Noer S, Nurhayati S. Bioaktivitas Ulva reticulate Forsskal. Asal gili kondo Lombok timur terhadap bakteri. Jurnal biotika. 2006;5(1); p. 45-60

12. Cowan M. Plant product as antimicrobial. Clinical microbiology reviews. 1999;12(4); p. 564-82

13. Strobel G, Daisy B. Bioprospecting for Microbial Endophytes and Their Natural Products. Microbiology and Molecular Biology. Review. 2003;67(4): 491-502. 
Putri, Posangi, Nangoy, Bara: Uji daya hambat...

14. Jawetz ZE, Melnick, Adeberg. Mikrobiologi Kedokteran. Edisi 20, diterjemahkan oleh: Edi, N, dan R.F. Maulany. ECG, Jakarta

15. Aidilfiet C, Suharo. Sterilisasi dan Desinfeksi: Staf Pengajar Bagian
Mikrobiologi Fakultas Kedokteran Universitas Indonesia. Buku Ajar Mikrobiologi Kedokteran. Edisi revisi. Jakarta: Binarupa Aksara: 2010. p. 55-69. 